\title{
Introduction to the Biogeochemistry from the Oligotrophic to the Ultraoligotrophic Mediterranean (BOUM) experiment
}

\author{
T. Moutin ${ }^{1}$, F. Van Wambeke ${ }^{1}$, and L. Prieur ${ }^{2}$ \\ ${ }^{1}$ Aix-Marseille Université, Université du Sud Toulon-Var, CNRS/INSU, UMR 6535, IRD, Mediterranean Institute of \\ Oceanography MIO, UM 110, 13288, Marseille, Cedex 09, France \\ ${ }^{2}$ Laboratoire d'Océanographie de Villefranche, CNRS/INSU UMR 7093, Université Pierre et Marie Curie, Observatoire \\ Océanologique de Villefranche, Villefranche sur mer, France
}

Correspondence to: T. Moutin (thierry.moutin@univ-amu.fr)

Received: 1 August 2011 - Published in Biogeosciences Discuss.: 10 August 2011

Revised: 20 July 2012 - Accepted: 10 August 2012 - Published: 8 October 2012

\begin{abstract}
The overall goal of the BOUM (Biogeochemistry from the Oligotrophic to the Ultraoligotrophic Mediterranean) experiment was to obtain a better representation of the interactions between planktonic organisms and the cycle of biogenic elements in the Mediterranean Sea (MS), in the context of global climate change and, more particularly, on the role of the ocean in carbon sequestration through biological processes. The BOUM experiment was organized around three main objectives: (1) to give a longitudinal description of the biogeochemistry and the biological diversity of the MS during the strongest stratified period, (2) to study processes at the centre of three anticyclonic eddies, and (3) to obtain a representation of the main biogeochemical fluxes and the dynamics of the planktonic trophic network. The international BOUM cruise took place between 16 June and 20 July 2008, involved 32 scientists on board, and covered around $3000 \mathrm{~km}$ in the MS from the south of Cyprus to Marseilles (France). This paper describes in detail the objectives of the BOUM experiment, the implementation plan of the cruise before giving an introduction of the 25 other papers published in this special issue.
\end{abstract}

\section{General context}

The additional $\mathrm{CO}_{2}$ in the atmosphere, mainly resulting from fossil fuel emissions linked to human activities (anthropogenic $\mathrm{CO}_{2}$ ), is the main cause of global warming.
The ocean has acted as a major sink of anthropogenic $\mathrm{CO}_{2}$ (Sabine et al., 2004) preventing a greater accumulation in the atmosphere and therefore a greater increase in the earth temperature. Although the biological pump (Fig. 1) provides the main explanation for the vertical gradient of carbon in the ocean, it was thought to be in an equilibrium state with an associated near-zero net exchange of $\mathrm{CO}_{2}$ with the atmosphere (Broecker 1991, Murname et al., 1999). Climate alterations are beginning to disrupt this equilibrium, and the expected modification of the biological pump will probably considerably influence oceanic carbon sequestration (and therefore global warming) over a decadal time scale (Sarmiento and Grüber, 2006).

$\mathrm{CO}_{2}$ is exchanged at the atmosphere-ocean interface and reacts with carbonate ions (Fig. 1). The time scale for reaching equilibrium within the upper layer is about a year (Kleypas and Langdon, 2006). This dissolved inorganic carbon is then transported much more slowly into deeper layers via mixing. This second step limits the sequestration of anthropogenic $\mathrm{CO}_{2}$ in the ocean on a decadal time scale and therefore influences the accumulation of $\mathrm{CO}_{2}$ in the atmosphere and thus, subsequent climate alteration (Sarmiento and Grüber, 2006). Some of the $\mathrm{CO}_{2}$ in the upper layer is incorporated into biomass by photosynthesis. This synthesis of particulate organic carbon is essentially dependent on the availability of light and nutrients (including trace metals). A fraction of the particulate organic carbon pool is transferred into the dissolved organic pool (Maranon et al., 2005). Most 


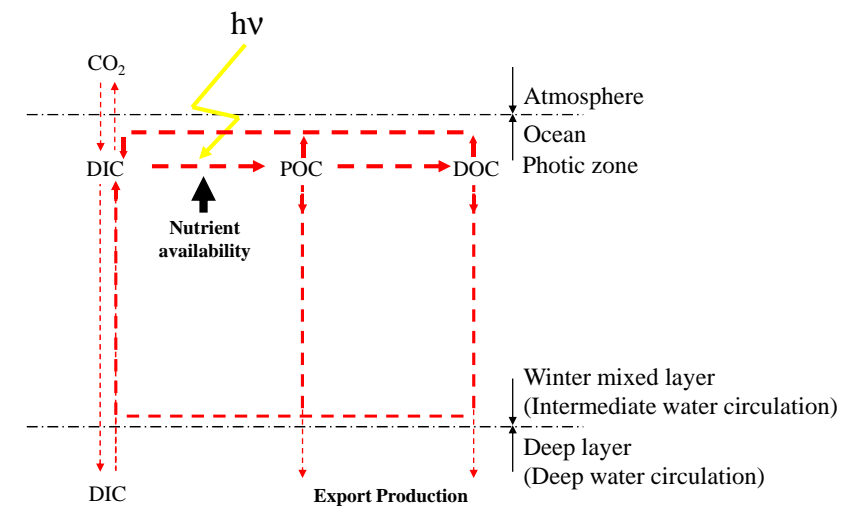

Fig. 1. Major carbon fluxes for a biological pump budget. Biological pump: carbon transfer by biological processes into the ocean interior. DIC: dissolved inorganic carbon, POC: particulate organic carbon, DOC: dissolved inorganic carbon. Modified from Moutin et al. (2000).

of the organic carbon is recycled in the upper surface layer, and the $\mathrm{CO}_{2}$ produced is re-exchanged with the atmosphere over a short time scale. Only a fraction of the organic carbon is exported to the ocean interior and constitutes the biological pump (Fig. 1).

Predictions in the 21st century seem to indicate an oligotrophication of the open ocean, resulting in a weakening of the transfer of carbon to the ocean interior and a concomitant acceleration of climate change (Boyd and Doney, 2003; Le Quéré et al., 2009). In order to determine the actual efficiency of the biological pump and to forecast its future efficiency, major challenges today concern biogeochemical, physical and biological oceanography. Major questions arise, of which one is central: What is the balance between production of organic matter in the photic layer, and remineralisation in the upper layer?

The input of new nutrients and particularly of new nitrogen in the photic zone is considered as the first criterion in oceanic fertility (Minas et al., 1988). Nevertheless, sequestration of anthropogenic $\mathrm{CO}_{2}$ depends on a budget which takes greater depth into account. It is important to know what fraction of export production escapes mineralisation on a decadal time scale (Fig. 1) and is then exported to deeper depths, i.e. to know what fraction will reach deep circulation. In this context, two mainly unresolved questions may arise.

First, what are the main processes controlling the vertical exchanges of nutrients and organic matter, and, in particular, what is the role of mesoscale activity and its links with water circulation? It was recently demonstrated that mesoscale activities may largely influence planktonic communities (D'Ovidio et al., 2010) and the global biogeochemical budget (Lévy, 2008). Because of their relatively simple physical structure, anticyclonic eddies have been much studied and their biogeochemical role has been principally considered to be the isolation of water (Chapman and Nof,
1988), leading towards higher oligotrophic conditions inside the eddies. However, their role in vertical exchanges of nutrients and organic matter linked with water circulation, despite their importance for the biological pump, is not as well understood.

Second, what is the influence of the complex relationships between organisms (What do we find when we open the living POC pool box)? A "world" exists between our oversimplified biogeochemical view of the biological pump (Fig. 1) and the real, multiple and complex relationships (predation, competition, symbiosis, commensalism, parasitism...) which actually exist between organisms in the upper water. It is true that we need not only to better describe and understand these relationships (biological population dynamics studies), but we also need to be able to simplify them in more simple functional schemes allowing to address central questions concerning global change and, for example, the role of the sea in carbon sequestration (biogeochemical studies). These two approaches should be conducted simultaneously with increasing interactions for as long as we remain unable to describe fluxes at the level of individual organisms in the global "earth-ocean-atmosphere" model of the carbon cycle. It is of particular interest to apply these general questions to oligotrophic areas. Oceanic oligotrophic areas represent more than $50 \%$ of the global ocean and about $40 \%$ of total oceanic production (Antoine et al., 1996). However, the functioning and productivity of oligotrophic systems, particularly the balance between production and mineralisation in these areas, is still the subject of much debate (Karl et al., 2003; Williams et al., 2004; Serret et al., 2006). Recent research has shown that these systems, which were once thought to be biological deserts, may contribute significantly to the total oceanic organic carbon export (Karl and Letelier, 2009; Kähler et al., 2010). It is thus important to thoroughly understand these vast ecosystems in order to be able to characterise them and to predict any modifications that may occur due to future environmental changes. Among oligotrophic areas, the low-P low chlorophyll (LPLC) areas such as the Sargasso Sea (Wu et al., 2000; Lomas et al., 2010) or the Mediterranean Sea (MS) are of further interest because a decrease in phosphate availability is the most probable decadal trend to occur with the onset of climate change (Moutin et al., 2008). The general trend seems to be towards an extension of LPLC areas, which reinforces our need to better understand their role in the carbon cycle.

\section{The Mediterranean Sea and the oligotrophic ocean}

Oligotrophic marine areas are characterized by a more or less pronounced thermal stratification of the water column, which delimits (1) a warm surface mixed layer with high light intensity but is depleted in nutrients and (2) a sub-superficial layer with low light levels and more nutrients. Tropical areas, including large anticyclonic gyres, the Sargasso Sea and 
the MS, have long been considered as typical oligotrophic systems (Herbland and Voituriez, 1977). The depth at which nitrate concentration falls below $50 \mathrm{nM}$ (quantification limit) during the stratified period is around $10 \mathrm{~m}$ in the Alboran area close to the Strait of Gibraltar, and can reach more than $150 \mathrm{~m}$ in the eastern basin of the MS (Moutin and Raimbault, 2002). This is related to hydrological conditions and particularly to higher winter convection in the western basin. The great nitracline depth in the Levantine basin (the easternmost basin of the eastern MS) is found elsewhere only in ultraoligotrophic conditions, as for example, in the centre of the South Pacific gyre (Moutin et al., 2008) which is considered as the most oligotrophic area of the ocean (Claustre and Maritorena, 2003). A decreasing trend in primary production was observed during a previous cruise transect in 1996 (MINOS cruise), with a western basin oligotrophy (mean depth of the top of the nitracline around $50-100 \mathrm{~m}$ and primary production rates around $200-400 \mathrm{mgC} \mathrm{m}^{-2} \mathrm{~d}^{-1}$ ) as generally observed in the oligotrophic open ocean (Moutin and Raimbault, 2002), and an eastern basin oligotrophy (depth of the top of the nitracline below $150 \mathrm{~m}$ and primary production rates below $200 \mathrm{mgC} \mathrm{m}^{-2} \mathrm{~d}^{-1}$ ) found to be as extreme as that observed in the South Pacific gyre (Moutin, unpublished result). On a regional scale, the MS presents the main oceanographic features of contrasting environments characteristic of the oligotrophic ocean.

Phosphate concentrations are close to the analytical detection limits in oligotrophic surface waters, and, because of this, phosphate turnover time $\left(\mathrm{T}_{\mathrm{PO} 4}\right)$, which represents the ratio between natural concentration and uptake by planktonic species (Thingstad et al., 1993), is considered as the most reliable measurement of phosphate availability at the present time. $\mathrm{T}_{\mathrm{PO} 4}$ varied between several hours in the MS and the Sargasso Sea during the stratified season and several months in the SP gyre, despite all these environments being oligotrophic; this allowed us to distinguish clearly between low$\mathrm{P}$ and high-P low chlorophyll areas: LPLC areas such as the MS or the Sargasso Sea with $\mathrm{T}_{\mathrm{PO} 4} \ll 50 \mathrm{~h}$ in comparison to HPLC areas like the SP gyre with $\mathrm{T}_{\mathrm{PO} 4} \gg 50 \mathrm{~h}$ in the upper surface stratified waters (Moutin et al., 2008).

Nutrient limitation of organic production has been widely studied in the MS and, although there is consensus as to the major control exerted by phosphate availability (Berland et al., 1980; Krom et al., 1991; Vaulot et al., 1996; Diaz et al., 2001; Moutin et al., 2002; Van Wambeke et al., 2002; Thingstad et al., 2005, Siokou-Frangou et al., 2010), nitrogen is also scarce, and the availability of silicic acid may play a central role in controlling the export of production (Leblanc et al., 2003). Biological diversity may reflect multiple organic production limitations.

The MS has a wide range of oligotrophic conditions suitable for studying the transformation of organic matter in marine food webs during low new nutrient availability and provides a case study for observing the links between the $\mathrm{C}, \mathrm{N}, \mathrm{P}$, and Si-cycles. Comparisons between different systems along a longitudinal gradient of trophic status provide new insights for identifying and understanding fundamental interactions between marine biogeochemistry and ecosystems.

\section{Objectives of the BOUM experiment}

The BOUM (Biogeochemistry from the Oligotrophic to the Ultraoligotrophic Mediterranean) experiment has one overall goal: to obtain a better representation of the interactions between planktonic organisms and the cycle of biogenic elements, considering spatial scales from one anticyclonic eddy to the whole MS. It is organized along three main objectives:

1. to give a longitudinal description of the biogeochemistry and biological diversity of the MS during the strongest stratified period.

2. to study the production and fate of organic matter in three oligotrophic environments located at the centre of anticyclonic eddies, with particular attention to the processes that drive the divergence of the stoichiometric ratios of the biogenic elements in the organic matter found in the surrounding water and in exported materials.

3. to obtain a satisfactory representation of the main biogeochemical fluxes (C, N, P, Si) and the dynamics of the planktonic network, both in situ and through microcosm experiments.

\section{Implementation of the BOUM cruise}

The BOUM cruise took place during the summer of 2008 (16 June-20 July). The $3000 \mathrm{~km}$ transect, surveyed using the French research vessel l'Atalante, stretched from the Eratosthenes Seamount in the eastern part of the MS to the Rhône river mouth in the western part (Fig. 2). Along this transect, two types of stations (Table 1) were sampled: the so-called "short duration" (SD) and "long duration" (LD) stations at the centres of anticyclonic eddies.

Thirty stations (27 SD stations + one profile at each LD station) were investigated from surface to bottom. Each of the three LD stations was investigated over four days with a CTD cast $(0-500 \mathrm{~m})$ every $3 \mathrm{~h}$, and specific operations (see below) were carried out between the CTD casts. The approximate locations of the LD stations were determined using previous work and satellite imagery (IR images from I. TaupierLetage, G. Rougier and G. Zodiatis, sea colour images from E. Bosc (Fig. 2 top and middle); all images were transmitted on board) as well as the MERCATOR forecast (www. mercator-ocean.fr). The exact locations of the LD stations were determined on board (1) from a rapid survey (Fig. 2, bottom) using XBT (roughly 10 T-7 type XBT) launched every $50 \mathrm{~min}$ at a vessel speed of approximately 11 knots, and (2) using thermosalinograph and ADCP data obtained from a CTD cast $(0-500 \mathrm{~m})$ grid of 16 stations spaced every 3 

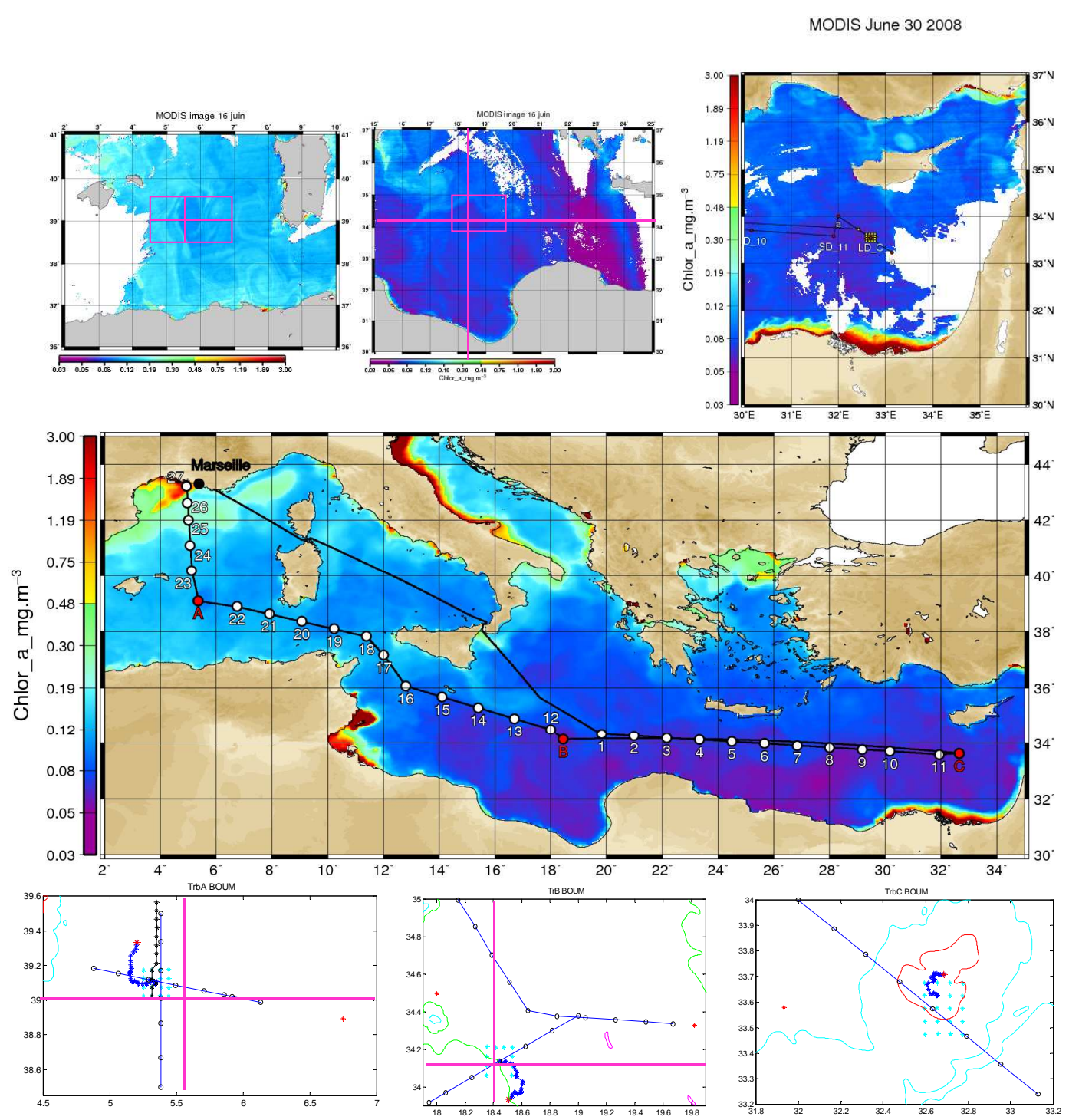

Fig. 2. Middle: transect of the BOUM cruise superimposed on a SeaWiFS composite image of Chl $a$ concentration in the upper layer of the MS between 16 June and 20 July 2008. The two types of stations, short duration and long duration, are indicated. The three LD stations investigated for a period longer than four days are indicated in red and are located in the centre of an anticyclonic eddy (courtesy of E. Bosc). Top: small size colour images indicating the location of eddies prior to sampling. The rectangles in red correspond to the maps detailed below. Bottom: XBT survey (black circles) and sampling grid stations (cyan crosses) investigated to locate eddy centres. An additional south-to-north CTD cast section is shown for eddy A (in black). The locations of each 0-500 dbars cast for the LD stations are shown in blue indicating estimates of the drifting of the eddy centres during 3 days. The red crosses indicate the locations of the deep casts performed at the end of LD station occupation. The 1000, 2000 and $3000 \mathrm{~m}$ bottom depths isolines are indicated in red, cyan and green, respectively. All figures could be increased in size on the screen to get all the details.

miles and centred around the presumed centre of each eddy (Fig. 2, Bottom). A mooring line (equipped with two PPS5 sediment traps, current meters, specific oxygen sensors, specific high frequency temperature sensors; consult: http://mio. pytheas.univ-amu.fr/BOUM/spip.php?article75 for an illustration) was then deployed at the centre of each eddy to start the process study. Simultaneously, a first PROVOR ARGO float (Bio) was deployed (Table 2). The mooring line was recovered at the end of occupation of each LD station, im- mediately following the last CTD cast from surface to bottom. A second PROVOR ARGO float (CTS3) was then deployed before departure to another station (Table 2). Specific operations during the LD station occupation consisted of radiometric cast, marine video profiler cast, clean pumping for trace metals sampling, profiles of turbulence measurements (Scamp), profiles of current measurements, hauls for phytoplankton and zooplankton sampling with specific nets. 
Table 1. Date, location and general characteristics of the stations investigated along the BOUM transect. Distance ( $\mathrm{km})$ : distance from the Rhône river mouth (SD27).

\begin{tabular}{|c|c|c|c|c|c|c|c|c|c|c|c|}
\hline \multicolumn{2}{|c|}{ Station } & \multirow{2}{*}{$\begin{array}{c}\text { CTD cast } \\
193\end{array}$} & \multirow{2}{*}{$\begin{array}{c}\text { Date } \\
18 \text { July }\end{array}$} & \multicolumn{3}{|c|}{ Latitude $\left({ }^{\circ}\right.$ and $\left.\min \right)$} & \multicolumn{3}{|c|}{ Longitude $\left({ }^{\circ}\right.$ and $\mathrm{min}$ ) } & \multirow{2}{*}{$\begin{array}{c}\text { Bottom Depth }(\mathrm{m}) \\
105\end{array}$} & \multirow{2}{*}{$\begin{array}{c}\text { Distance }(\mathrm{km}) \\
0\end{array}$} \\
\hline 27 & SD & & & 43 & 12.70 & $\mathrm{~N}$ & 4 & 55.80 & E & & \\
\hline 26 & SD & 192 & 18 July & 42 & 37.00 & $\mathrm{~N}$ & 4 & 57.30 & $\mathrm{E}$ & 1721 & 67 \\
\hline 25 & SD & 190 & 18 July & 41 & 59.80 & $\mathrm{~N}$ & 5 & 0.00 & E & 2258 & 136 \\
\hline 24 & SD & 188 & 17 July & 41 & 5.30 & $\mathrm{~N}$ & 5 & 3.40 & $\mathrm{E}$ & 2663 & 237 \\
\hline 23 & SD & 187 & July 17 & 40 & 10.70 & $\mathrm{~N}$ & 5 & 6.70 & E & 2786 & 338 \\
\hline A & LD & 186 & 11-17 July & 39 & 5.96 & $\mathrm{~N}$ & 5 & 21.00 & $\mathrm{E}$ & 2758 & 433 \\
\hline 22 & SD & 130 & 11 July & 38 & 53.70 & $\mathrm{~N}$ & 6 & 45.08 & $\mathrm{E}$ & 2864 & 575 \\
\hline 21 & SD & 128 & 11 July & 38 & 37.85 & $\mathrm{~N}$ & 7 & 54.58 & $\mathrm{E}$ & 2159 & 679 \\
\hline 20 & SD & 127 & 10 July & 38 & 21.80 & $\mathrm{~N}$ & 9 & 3.90 & $\mathrm{E}$ & 1758 & 784 \\
\hline 19 & SD & 125 & 10 July & 38 & 5.90 & $\mathrm{~N}$ & 10 & 13.40 & E & 519 & 889 \\
\hline 18 & SD & 124 & 9 July & 37 & 49.90 & $\mathrm{~N}$ & 11 & 23.00 & E & 771 & 995 \\
\hline 17 & SD & 122 & 9 July & 37 & 10.00 & $\mathrm{~N}$ & 12 & 0.08 & E & 117 & 1087 \\
\hline 16 & SD & 121 & 9 July & 36 & 3.93 & $\mathrm{~N}$ & 12 & 48.06 & E & 861 & 1229 \\
\hline 15 & SD & 119 & 8 July & 35 & 40.45 & $\mathrm{~N}$ & 14 & 6.00 & E & 588 & 1354 \\
\hline 14 & SD & 118 & 8 July & 35 & 17.00 & $\mathrm{~N}$ & 15 & 24.10 & E & 382 & 1480 \\
\hline 13 & SD & 116 & 7 July & 34 & 53.50 & $\mathrm{~N}$ & 16 & 42.00 & E & 2097 & 1606 \\
\hline 12 & SD & 115 & 7 July & 34 & 30.13 & $\mathrm{~N}$ & 18 & 0.02 & E & 3321 & 1732 \\
\hline B & LD & 114 & 3-7 July & 34 & 8.20 & $\mathrm{~N}$ & 18 & 26.70 & E & 3070 & 1810 \\
\hline 1 & SD & 2 & 21 June & 34 & 19.66 & $\mathrm{~N}$ & 19 & 49.20 & E & 3210 & 1939 \\
\hline 2 & SD & 4 & 21 June & 34 & 15.57 & $\mathrm{~N}$ & 20 & 59.12 & E & 2593 & 2046 \\
\hline 3 & SD & 5 & 21 June & 34 & 10.90 & $\mathrm{~N}$ & 22 & 9.50 & E & 2382 & 2155 \\
\hline 4 & SD & 7 & 22 June & 34 & 7.00 & $\mathrm{~N}$ & 23 & 19.67 & E & 2471 & 2262 \\
\hline 5 & SD & 8 & 22 June & 34 & 2.70 & $\mathrm{~N}$ & 24 & 29.80 & E & 2616 & 2370 \\
\hline 6 & SD & 10 & 23 June & 33 & 58.49 & $\mathrm{~N}$ & 25 & 40.06 & E & 2761 & 2478 \\
\hline 7 & SD & 11 & 23 June & 33 & 54.20 & $\mathrm{~N}$ & 26 & 50.20 & E & 2784 & 2586 \\
\hline 8 & SD & 13 & 23 June & 33 & 49.90 & $\mathrm{~N}$ & 28 & 0.30 & E & 2768 & 2694 \\
\hline 9 & SD & 14 & 24 June & 33 & 45.70 & $\mathrm{~N}$ & 29 & 10.50 & E & 3033 & 2803 \\
\hline 10 & SD & 16 & 24 June & 33 & 41.90 & $\mathrm{~N}$ & 30 & 9.60 & E & 2942 & 2894 \\
\hline 11 & SD & 17 & 25 June & 33 & 34.82 & $\mathrm{~N}$ & 31 & 56.04 & E & 2514 & 3058 \\
\hline $\mathrm{C}$ & LD & 71 & 25-30 June & 33 & 37.50 & $\mathrm{~N}$ & 32 & 39.20 & $\mathrm{E}$ & 923 & 3130 \\
\hline
\end{tabular}

Table 2. PROVOR ARGO floats deployed along the BOUM transect at the three pre-defined LD stations (A, B, C).

\begin{tabular}{l|l|c|ccc|ccc}
\hline \multirow{2}{*}{ Station } & \multirow{2}{*}{ Float number } & \multirow{2}{*}{ Date of deployment } & \multicolumn{4}{|c}{ Deployment location } \\
& & Latitude & \multicolumn{4}{c}{ Longitude } \\
\hline A & WMO 6900664 & 17 July & 39 & 20.48 & N & 5 & 11.41 & E \\
B & (Pro Bio A) WMO 6900674 & 4 July & 34 & 7.97 & N & 18 & 26.70 & E \\
B & WMO 6900663 & 7 July & 33 & 56.87 & N & 18 & 27.29 & E \\
C & (Pro Bio B) WMO 6900679 & 26 June & 33 & 37.53 & N & 32 & 39.70 & E \\
C & WMO 6900665 & 30 June & 33 & 42.54 & N & 32 & 41.90 & E \\
\hline
\end{tabular}

Many details concerning the BOUM cruise are available with free access on the BOUM web site: http://mio.pytheas. univ-amu.fr/BOUM/

The general description of the main Mediterranean water masses encountered and general physical and biogeochemical characteristics of the stations investigated along the BOUM cruise-transect are presented in a separate paper by Moutin and Prieur (2012).

\section{Special issue presentation}

The goal of this special issue is to present the knowledge obtained concerning the functioning of the MS ecosystems and associated biogeochemical cycles based on the dataset acquired during the BOUM experiment. The cruise strategy was organized to promote collaborations between physicists, biogeochemists, biologists and modellers. Most of the 
contributions to this volume have benefited from this collective effort.

The 25 papers below are introduced according to the three main objectives of the BOUM experiment.

1. Longitudinal description of the biogeochemistry and biological diversity of the MS during the strongest stratified period.

The P depletion of the MS was confirmed particularly in the ultraoligotrophic eastern basin (Pujo-Pay et al., 2011) which definitively establishes the MS as one of the low-P low chlorophyll (LPLC, Moutin et al., 2008) areas in the world ocean. Following the nutriclines, parallel deep maxima of biogenic silica, of fucoxanthin, and of $T \operatorname{chl} a$ (Crombet at al., 2011) were found towards the east along with decreases in biomasses and production of diatoms (Crombet et al., 2011), of the major members of the heterotrophic microbial community (Christaki et al., 2011, Van Wambeke et al., 2011), of aerobic anoxygenic phototrophic (AAP) bacteria (Lamy et al., 2011, Jeanthon et al., 2011), and of metazooplankton (Nowaczyk et al., 2011). Contrary to the deep chlorophyll maximum, which was a persistent feature of the MS, the deep silica maximum correlated with the deep fucoxanthin maximum as was observed in discrete areas of each basin (Crombet et al., 2011). Interestingly, there was an eastward decreasing trend of $\mathrm{N}_{2}$ fixation (Bonnet et al., 2011). The majority of identified diazotrophs were isolated unicellular diazotrophic cyanobacteria of the picoplanktonic size fraction (Le Moal et al., 2011). Nevertheless, those living in association with diatoms were observed at nearly all sites (Crombet et al., 2011) giving an unexpected yet interesting coupling between the nitrogen and silicon cycles in the MS. Dissolved carbon production increases with strong nutrient limitation (López-Sandoval et al., 2011), which may also explain the greater DOC accumulation in the east and inside the eddies (Pujo-Pay et al., 2011, Moutin and Prieur, 2012). Following anthropogenic carbon sequestration, unprecedented levels of acidification are reached, which positions the MS as one of the most acidified world marine ecosystems (Touratier et al., 2012). Phospholipid concentration was found to correlate with phosphate concentration across the MS, and a rapid response of membrane lipid composition to changes in nutrients was demonstrated for the first time (Poppendorf et al., 2011). The on-board measurements of cell-specific radiolabelled leucine using flow cytometry coupled with cell sorting allowed us to reinforce the prevalent role of mixotrophs within the microbial communities of the MS (Talarmin et al., 2011). It was shown that dinospores may escape the severe nutrient limitation of ultraoligotrophic conditions by living inside copepods (Alves-de-Souza et al., 2011) and that they were able to thrive and infect dinoflagellates, both in coastal and ultraoligotrophic waters, emphasizing the overlooked role of parasitism in food webs and biogeochemical cycles (Siano et al., 2011). No major differences were observed in the genetic diversity of the cyanobacterial populations during the BOUM cruise (2008) and the previous PROSOPE cruise (1999), suggesting that local populations have not yet been displaced by their (sub)tropical counterparts (MellaFlores et al., 2011). The three geographically distant eddies, characterized by deep pycnostads below the photic zone, showed very different biogeochemical characteristics from the typical east-west trends observed in the BOUM section (Moutin and Prieur, 2012), and different ecosystems from surrounding waters (Christaki et al., 2011) probably principally because of the "closed" system conditions they experienced from the previous winter (Moutin and Prieur, 2012). They were chosen for process studies.

2. Process studies at the centre of the three anticyclonic eddies studied

We first provide evidence that locations of the $3 \mathrm{LD}$ stations studied were near the axis of the eddies which may be considered as almost closed systems after their formation, and showed that such mesoscale activity is strong enough to locally delete (or even reverse) the very well-known western-to-eastern gradient of trophic conditions in the MS (Moutin and Prieur, 2012). Primary production was similarly low inside each eddy and net community production close to zero (Christaki et al., 2011).

Process studies concern both in situ measurements and microcosm experiments. The first estimations of turbulent dissipation inside anticyclonic eddies give evidence for a significant increase at the top and base of eddies which can be associated with strong near-inertial waves (Cuypers et al., 2012). Vertical turbulent diffusivity is increased both in these regions and in the weakly stratified eddy core (Cuypers et al., 2012). This allows the quantification of nitrate flux by upward diffusion, which was low and of the same order of magnitude as input by $\mathrm{N}_{2}$ fixation (Bonnet et al., 2011). A daily $\mathrm{N}$-budget close to the equilibrium was found for the upper layer $(0-150 \mathrm{~m})$ inside the anticyclonic eddies (Moutin and Prieur, 2012). Contrary to the common view that siliceous phytoplankton are not key players in the MS, Crombet et al. (2011) suggest that they may contribute in a major way to marine production. Biooptical anomaly and diurnal variability of the particulate matter were studied. For the first time, the diel cycle of the particulate backscattering coefficient was observed from field measurements (Loisel et al., 2011). A new method for analysing diel cycles in particulate beam-attenuation coefficient measured at multiple 
wavelengths suggests that most of the observed variations can be ascribed to a synchronized population of cells with an equivalent spherical diameter of between 1-4 $\mu \mathrm{m}$ (Dall'Olmo et al., 2011).

Nutrient limitation of the pelagic microbial food web was investigated using amended microcosm experiments. A gap between biogeochemical features (an apparent P-starved status) and biological responses (no apparent P-limitation) was demonstrated (Tanaka et al., 2011) as well as an uncoupling of phytoplankton production and consumption by heterotrophic prokaryotes (Lagaria et al., 2011). Primary production significantly increased after addition of aerosols, indicating the relieving of on-going co-limitations (Ternon et al., 2011) and the strong stimulation of $\mathrm{N}_{2}$ fixation (Ridame et al., 2011).

3. Representation of the main biogeochemical fluxes and the dynamics of the planktonic trophic network.

An interesting schematic box plot representation of the biogeochemical functioning of the two Mediterranean basins was proposed by Pujo-Pay et al. (2011). Surprisingly, the nitrate vs. phosphate ratio $(\Delta \mathrm{N}: \Delta \mathrm{P}$, slope of the $\mathrm{N}$ vs. $\mathrm{P}$ regression line for a given layer) in the intermediate and deep layer tended towards the canonical Redfield value of 16 in both basins and their biogeochemical functioning showed a similar pattern.

A multi-element model using Eco3M (Ecological Mechanistic Modular tool) was implemented to understand how primary producers and remineralisers interact and control the overall DOC and nutrient dynamics. It was suggested that the unusually high $\mathrm{N}: \mathrm{P}$ ratio of the MS may favour the uncoupling between growth and carbon production, leading to higher DOC accumulation when compared to systems with lower $\mathrm{N}: \mathrm{P}$ ratio (Mauriac et al., 2011).

The next step will be to use the numerous data collected during the BOUM cruise (http://www.obs-vlfr.fr/proof/ php/x_datalist.php?xxop=boum\&xxcamp=boum) to implement physical models on the spatial scales of the eddy and of the whole MS, in order to study the influence exerted by the numerous anticyclonic eddies on anthropic carbon sequestration in the MS and on the decadal time scale.

Acknowledgements. This is a contribution of the BOUM (Biogeochemistry from the Oligotrophic to the Ultraoligotrophic Mediterranean) experiment (http://mio.pytheas.univ-amu.fr/BOUM/) of the French national LEFE-CYBER program, the European IP SESAME (D. Georgopoulos and V. Papathanassiou are warmly thanked) and the international IMBER project. The BOUM experiment was coordinated by the Institut des Sciences de l'Univers (INSU) and managed by the Centre National de la
Recherche Scientifique (CNRS). The authors thank the crew of the $\mathrm{R} / \mathrm{V}$ L'Atalante for their outstanding shipboard operations. C. Marec and L. Prieur are warmly thanked for their efficient help in CTD rosette management and data processing as is Marie Paule Torre for the LEFE CYBER database management. All data and metadata are available at the following web address:http://www. obs-vlfr.fr/proof/php/x_datalist.php?xxop=boum\&xxcamp=boum. Martine Aperio and Catherine Perrot are acknowledged for the administrative work.

Edited by: C. Jeanthon

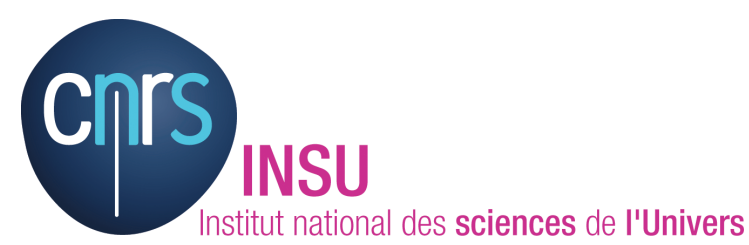

The publication of this article is financed by CNRS-INSU.

\section{References}

Alves-de-Souza, C., Cornet, C., Nowaczyk, A., Gasparini, S., Skovgaard, A., and Guillou, L.: Blastodinium spp. infect copepods in the ultra-oligotrophic marine waters of the Mediterranean Sea, Biogeosciences, 8, 2125-2136, doi:10.5194/bg-82125-2011, 2011.

Antoine, D., André, J. M., and Morel, A.: Oceanic primary production: II. Estimation at global scale from satellite (Coastal Zone Color Scanner) chlorophyll, Global Biogeochem. Cy., 10, 57-69, 1996.

Berland, B. R., Bonin, D. J. and Maestrini, S. Y.: Azote ou phosphore? Considérations sur le "paradoxe nutritionnel" de la mer méditerranée, Ocean. Ac., 3, 135-141, 1980.

Bonnet, S., Grosso, O., and Moutin, T.: Planktonic dinitrogen fixation along a longitudinal gradient across the Mediterranean Sea during the stratified period (BOUM cruise), Biogeosciences, 8 , 2257-2267, doi:10.5194/bg-8-2257-2011, 2011.

Boyd, P. W. and Doney, S. C.: The impact of climate change and feedback processes on the Ocean Carbon Cycle, in: Ocean Biogeochemistry - the role of the ocean carbon cycle in global change, edited by: Fasham, M. J. R., 157-187, Springer-Verlag, Berlin, 2003.

Broecker, W. S.: Keeping global change honest, Global Biogeochem. Cy., 1, 15-29, 1991.

Chapman, R. and Nof, D.: The sinking of Warm-Core rings, J. Phys. Oceanog., 18, 565-583, 1988.

Christaki, U., Van Wambeke, F., Lefevre, D., Lagaria, A., Prieur, L., Pujo-Pay, M., Grattepanche, J.-D., Colombet, J., Psarra, S., Dolan, J. R., Sime-Ngando, T., Conan, P., Weinbauer, M. G., and Moutin, T.: Microbial food webs and metabolic state across oligotrophic waters of the Mediterranean Sea during summer, Biogeosciences, 8, 1839-1852, doi:10.5194/bg-8-1839-2011, 2011.

Claustre, H. and Maritorena, S.: The Many Shades of Ocean Blue, Science, 302, 1514-1515, 2003.

Crombet, Y., Leblanc, K., Quéguiner, B., Moutin, T., Rimmelin, P., Ras, J., Claustre, H., Leblond, N., Oriol, L., and Pujo-Pay, 
M.: Deep silicon maxima in the stratified oligotrophic Mediterranean Sea, Biogeosciences, 8, 459-475, doi:10.5194/bg-8-4592011, 2011.

Cuypers, Y., Bouruet-Aubertot, P., Marec, C., and Fuda, J.-L.: Characterization of turbulence from a fine-scale parameterization and microstructure measurements in the Mediterranean Sea during the BOUM experiment, Biogeosciences, 9, 3131-3149, doi:10.5194/bg-9-3131-2012, 2012.

Dall'Olmo, G., Boss, E., Behrenfeld, M. J., Westberry, T. K., Courties, C., Prieur, L., Pujo-Pay, M., Hardman-Mountford, N., and Moutin, T.: Inferring phytoplankton carbon and ecophysiological rates from diel cycles of spectral particulate beam-attenuation coefficient, Biogeosciences, 8, 3423-3439, doi:10.5194/bg-8-3423-2011, 2011.

Diaz, F., Raimbault, P., Boudjellal, B., Garcia, N., and Moutin, T.: Early spring phosphorus limitation of primary productivity in a NW Mediterranean coastal zone (Gulf of Lions), Mar. Ecol. Progr. Ser., 211, 51-62, 2001.

D’Ovidio, F., De Monte, S., Alvain, S., Dandonneau, Y., and Lévy, M.: Fluid dynamical niches of phytoplankton types. Proc. Natl. Acad. Sci. USA, 107, 18366-18370, doi:10.1073/pnas.1004620107, 2010.

Herbland, A. and Voituriez, B.: Production primaire, nitrate et nitrite dans 1'Atlantique tropical. 1. Distribution du nitrate et production primaire. Cah. ORSTOM, (Sér. Océanogr.), 15, 47-56, 1977.

Jeanthon, C., Boeuf, D., Dahan, O., Le Gall, F., Garczarek, L., Bendif, E. M., and Lehours, A.-C.: Diversity of cultivated and metabolically active aerobic anoxygenic phototrophic bacteria along an oligotrophic gradient in the Mediterranean Sea, Biogeosciences, 8, 1955-1970, doi:10.5194/bg-8-1955-2011, 2011.

Kähler, P., Oschlies, A., Dietze, H., and Koeve, W.: Oxygen, carbon, and nutrients in the oligotrophic eastern subtropical North Atlantic, Biogeosciences, 7, 1143-1156, doi:10.5194/bg-7-11432010, 2010.

Karl, D. M. and Letelier, R. M.: Seascape microbial ecology: Habitat structure, biodiversity and ecosystem function, in: Levin, S. A., The Princeton Guide to Ecology, Princeton University Press, Princeton, New Jersey, 488-500, 2009.

Karl, D. M., Laws, E. A., Morris, P., Williams, P. J. leB, and Emerson, S.: Metabolic balance of the open sea, Nature, 426, 32, 2003.

Kleypas J. A. and Langdon, C.: Coral reefs and changing seawater chemistry, Chapter 5, in: Coral Reefs and Climate Change: Science and Management, edited by: Phinney, J. T., HoeghGuldberg, O., Kleypas, J. A., Skirving, W., and Strong, A., AGU Monograph Series, Coastal and Estuarine Studies, Am. Geophys. Union, Washington DC, 61, 73-110, 2006.

Krom, M. D., Kress, N., and Brenner, S.: Phosphorus limitation of primary productivity in the eastern Mediterranean Sea, Limnol. Oceanogr., 36, 424-432, 1991.

Lagaria, A., Psarra, S., Lefèvre, D., Van Wambeke, F., Courties, C., Pujo-Pay, M., Oriol, L., Tanaka, T., and Christaki, U.: The effects of nutrient additions on particulate and dissolved primary production and metabolic state in surface waters of three Mediterranean eddies, Biogeosciences, 8, 2595-2607, doi:10.5194/bg8-2595-2011, 2011.

Lamy, D., Jeanthon, C., Cottrell, M. T., Kirchman, D. L., Van Wambeke, F., Ras, J., Dahan, O., Pujo-Pay, M., Oriol, L., Bariat, L., Catala, P., Cornet-Barthaux, V., and Lebaron, P.: Ecology of aerobic anoxygenic phototrophic bacteria along an oligotrophic gradient in the Mediterranean Sea, Biogeosciences, 8, 973-985, doi:10.5194/bg-8-973-2011, 2011.

Leblanc, K., Queguiner, B., Garcia, N., Rimmelin, P., and Raimbault, P.: Silicon cycle in the Northwestern Mediterranean sea: seasonnal study of a coastal oligotrophic site, Ocean. Ac., 26, 339-356, 2003.

Lévy, M.: The modulation of biological production by oceanic mesoscal turbulence, Lect. Notes Phys., 744, 219-261, doi:10.1007/978-3-540-75215-8_9, Transport in Geophysical flow: Ten years after, edited by: Weiss, J. B. and Provenzale, A., Springler, 2008.

Le Quéré, C., Raupach, M. R., Canadell, J. G., Marland, G., Bopp, L., Ciais, P., Conway, T. J., Doney, S. C., Feely, R., Foster, P., Friedlingstein, P., Gurney, K., Houghton, R. A., House, J. I., Huntingford, C., Levy, P. E., Lomas, M. R., Majkut, J., Metzl, N., Ometto, J. P., Peters, G. P., Prentice, I. C., Randerson, J. T., Running, S. W., Sarmiento, J. L., Schuster, U., Sitch, S., Takahashi, T., Viovy, N., van der Werf, G. R., and Woodward, F. I.: Trends in the sources and sinks of carbon dioxide, Nat. Geosci., 2, 831-836, doi:10.1038/ngeo689, 2009.

Le Moal, M., Collin, H., and Biegala, I. C.: Intriguing diversity among diazotrophic picoplankton along a Mediterranean transect: a dominance of rhizobia, Biogeosciences, 8, 827-840, doi:10.5194/bg-8-827-2011, 2011.

Loisel, H., Vantrepotte, V., Norkvist, K., Mériaux, X., Kheireddine, M., Ras, J., Pujo-Pay, M., Combet, Y., Leblanc, K., Dall'Olmo, G., Mauriac, R., Dessailly, D., and Moutin, T.: Characterization of the bio-optical anomaly and diurnal variability of particulate matter, as seen from scattering and backscattering coefficients, in ultra-oligotrophic eddies of the Mediterranean Sea, Biogeosciences, 8, 3295-3317, doi:10.5194/bg-8-3295-2011, 2011.

Lomas, M. W., Burke, A. L., Lomas, D. A., Bell, D. W., Shen, C., Dyhrman, S. T., and Ammerman, J. W.: Sargasso Sea phosphorus biogeochemistry: an important role for dissolved organic phosphorus (DOP), Biogeosciences, 7, 695-710, doi:10.5194/bg-7695-2010, 2010.

López-Sandoval, D. C., Fernández, A., and Marañón, E.: Dissolved and particulate primary production along a longitudinal gradient in the Mediterranean Sea, Biogeosciences, 8, 815-825, doi:10.5194/bg-8-815-2011, 2011.

Marañón, E., Cermeño, P., and Pérez, V.: Continuity in the photosynthetic production of dissolved organic carbon from eutrophic to oligotrophic waters, Mar. Ecol. Prog.-Ser., 299, 7-17, 2005.

Mauriac, R., Moutin, T., and Baklouti, M.: Accumulation of DOC in Low Phosphate Low Chlorophyll (LPLC) area: is it related to higher production under high N:P ratio?, Biogeosciences, 8 , 933-950, doi:10.5194/bg-8-933-2011, 2011.

Mella-Flores, D., Mazard, S., Humily, F., Partensky, F., Mahé, F., Bariat, L., Courties, C., Marie, D., Ras, J., Mauriac, R., Jeanthon, C., Mahdi Bendif, E., Ostrowski, M., Scanlan, D. J., and Garczarek, L.: Is the distribution of Prochlorococcus and Synechococcus ecotypes in the Mediterranean Sea affected by global warming?, Biogeosciences, 8, 2785-2804, doi:10.5194/bg-82785-2011, 2011.

Minas, H. J., Minas, M., Coste, B., Gostan, J., Nival, P., and Bonin, M. C.: Production de base et de recyclage ; une revue de la problématique en Méditerranée nord-occidentale., $\mathrm{n}^{\circ}$ spécial: Océanographie pélagique méditerranéenne, Minas et Nival (eds), 
Oceanol. Ac., 155-162, 1988.

Moutin, T.: Cycle biogéochimique du phosphate: rôle dans le contrôle de la production planctonique et conséquences sur l'exportation de carbone de la couche éclairée vers l'océan profond, Océanis, 36-4, 2000.

Moutin, T. and Prieur, L.: Influence of anticyclonic eddies on the Biogeochemistry from the Oligotrophic to the Ultraoligotrophic Mediterranean (BOUM cruise), Biogeosciences, 9, 3827-3855, doi:10.5194/bg-9-3827-2012, 2012.

Moutin, T. and Raimbault, P.: Primary production, carbon export and nutrients availability in western and eastern Mediterranean Sea in early summer 1996 (MINOS cruise), J. Mar. Syst., 33/34, 273-288, 2002.

Moutin, T., Karl, D. M., Duhamel, S., Rimmelin, P., Raimbault, P., Van Mooy, B. A. S., and Claustre, H.: Phosphate availability and the ultimate control of new nitrogen input by nitrogen fixation in the tropical Pacific Ocean, Biogeosciences, 5, 95-109, doi:10.5194/bg-5-95-2008, 2008.

Moutin, T., Thingstad, T. F., Van Wambeke, F., Marie, D., Slawyk, G., Raimbault, P. and Claustre, H.: Does competition for nano-molar phosphate supply explain the predominance of the cyanobacterium Synechococcus? Limnol. Oceanogr., 47, 15621567, 2002.

Murnane, R., Sarmiento, J. L. and Le Quéré, C. L.: Spatial distribution of air-sea $\mathrm{CO}_{2}$ fluxes and the interhemispheric transport of carbon by the oceans, Global Biogeochem. Cy., 13, 287-305, 1999.

Nowaczyk, A., Carlotti, F., Thibault-Botha, D., and Pagano, M.: Distribution of epipelagic metazooplankton across the Mediterranean Sea during the summer BOUM cruise, Biogeosciences, 8, 2159-2177, doi:10.5194/bg-8-2159-2011, 2011.

Popendorf, K. J., Tanaka, T., Pujo-Pay, M., Lagaria, A., Courties, C., Conan, P., Oriol, L., Sofen, L. E., Moutin, T., and Van Mooy, B. A. S.: Gradients in intact polar diacylglycerolipids across the Mediterranean Sea are related to phosphate availability, Biogeosciences, 8, 3733-3745, doi:10.5194/bg-8-3733-2011, 2011.

Pujo-Pay, M., Conan, P., Oriol, L., Cornet-Barthaux, V., Falco, C., Ghiglione, J.-F., Goyet, C., Moutin, T., and Prieur, L.: Integrated survey of elemental stoichiometry $(\mathrm{C}, \mathrm{N}, \mathrm{P})$ from the western to eastern Mediterranean Sea, Biogeosciences, 8, 883899, doi:10.5194/bg-8-883-2011, 2011.

Ridame, C., Le Moal, M., Guieu, C., Ternon, E., Biegala, I. C., L'Helguen, S., and Pujo-Pay, M.: Nutrient control of $\mathrm{N}_{2}$ fixation in the oligotrophic Mediterranean Sea and the impact of Saharan dust events, Biogeosciences, 8, 2773-2783, doi:10.5194/bg8-2773-2011, 2011.

Sabine, C. L., Feely, R. A., Gruber, N., Key, R. M., Lee, K., and Bullister, J. L.: The oceanic sink for anthropogenic $\mathrm{CO}_{2}$, Science, 305, 367-371, 2004.

Sarmiento, J. L. and Gruber, N.: Ocean Biogeochemical Dynamics, Princeton University Press, Princeton, 503 pp, 2006.

Serret, P., Fernandez, E., Robinson, C. E. Malcolm S. Woodward, M. S., and Perez, V.: Local production does not control the balance between plankton photosynthesis and respiration in the open Atlantic Ocean. Deep-Sea Res. Pt. II, 53, 1611-1628, 2006.

Siano, R., Alves-de-Souza, C., Foulon, E., Bendif, El M., Simon, N., Guillou, L., and Not, F.: Distribution and host diversity of Amoebophryidae parasites across oligotrophic waters of the Mediterranean Sea, Biogeosciences, 8, 267-278, doi:10.5194/bg-8-267-2011, 2011.

Siokou-Frangou, I., Christaki, U., Mazzocchi, M. G., Montresor, M., Ribera d'Alcalá, M., Vaqué, D., and Zingone, A.: Plankton in the open Mediterranean Sea: a review, Biogeosciences, 7, 15431586, doi:10.5194/bg-7-1543-2010, 2010.

Talarmin, A., Van Wambeke, F., Catala, P., Courties, C., and Lebaron, P.: Flow cytometric assessment of specific leucine incorporation in the open Mediterranean, Biogeosciences, 8, 253265, doi:10.5194/bg-8-253-2011, 2011.

Tanaka, T., Thingstad, T. F., Christaki, U., Colombet, J., CornetBarthaux, V., Courties, C., Grattepanche, J.-D., Lagaria, A., Nedoma, J., Oriol, L., Psarra, S., Pujo-Pay, M., and Van Wambeke, F.: Lack of P-limitation of phytoplankton and heterotrophic prokaryotes in surface waters of three anticyclonic eddies in the stratified Mediterranean Sea, Biogeosciences, 8, 525-538, doi:10.5194/bg-8-525-2011, 2011.

Ternon, E., Guieu, C., Ridame, C., L'Helguen, S., and Catala, P.: Longitudinal variability of the biogeochemical role of Mediterranean aerosols in the Mediterranean Sea, Biogeosciences, 8, 1067-1080, doi:10.5194/bg-8-1067-2011, 2011.

Thingstad, T. F., Krom, M. D., Mantoura, R. F. C., Flaten, G. A. F., Groom, S., Herut, B., Kress, N., Law, C., Pasternak, A., Pitta, P., Psarra, S., Rassoulzadegan, F., Tanaka, T., Tselipides, A., Wassmann, P., Woodward, E. M. S., Wexels Riser, C., Zodiatis, G., and Zohary, T.: Nature of $\mathrm{P}$ limitation in the ultraoligotrophic Eastern Mediterranean, Science, 309, 1068-1071, 2005.

Thingstad, T. F., Skjoldal, E. F., and Bohne. R. A.: Phosphorus cycling and algal-bacterial competition in Sandsfjord, western Norway, Mar. Ecol. Prog. Ser., 99, 239-259, 1993.

Touratier, F., Guglielmi, V., Goyet, C., Prieur, L., Pujo-Pay, M., Conan, P., and Falco, C.: Distributions of the carbonate system properties, anthropogenic $\mathrm{CO}_{2}$, and acidification during the 2008 BOUM cruise (Mediterranean Sea), Biogeosciences Discuss., 9, 2709-2753, doi:10.5194/bgd-9-2709-2012, 2012.

Van Wambeke, F., Christaki, U., Giannakourou, A., Moutin, T., and Souvemerzoglou, K.: Longitudinal and vertical trends of bacterial limitation by phosphorus and carbon in the Mediterranean sea, Microb. Ecol., 43, 119-133, 2002.

Van Wambeke, F., Catala, P., Pujo-Pay, M., and Lebaron, P.: Vertical and longitudinal gradients in HNA-LNA cell abundances and cytometric characteristics in the Mediterranean Sea, Biogeosciences, 8, 1853-1863, doi:10.5194/bg-8-1853-2011, 2011.

Vaulot, D., Lebot, N., Marie, D., and Fukai, E.: Effect on phosphorus on the Synechococcus cell cycle i,n Surface Mediterranean Waters during Summer, Appl. Environ. Microbiol., 62, 25272533, 1996.

Williams, P. J. leB., Morris P. J., and Karl, D. M.: Net community production and metabolic balance at the oligotrophic ocean site, station ALOHA. Deep-Sea Res. I, 51, 1563-1578, 2004.

Wu, J., Sunda, W., Boyle, E. A., and Karl, D. M.: Phosphate depletion in the western North Atlantic Ocean, Science, 289, 759-762, 2000 . 